\title{
Purification, Characterization of L-Methioninase from Candida tropicalis, and Its Application as an Anticancer
}

\author{
Mohsen Helmy Selim, ${ }^{1}$ El-Zahraa Karm Eldin, ${ }^{2}$ Moataza Mahmoud Saad, \\ El-Sayed Eliwa Mostafa, ${ }^{1}$ Yosrea Hassan Shetia, ${ }^{2}$ and Amany Ahmed Hassabo Anise ${ }^{1}$ \\ ${ }^{1}$ National Research Centre, P.O. Box 12622, Dokki, Giza, Egypt \\ ${ }^{2}$ Faculty of Science, Ain Shams University, Cairo, Egypt
}

Correspondence should be addressed to Moataza Mahmoud Saad; moataza_saad@yahoo.com

Received 28 July 2015; Revised 10 October 2015; Accepted 13 October 2015

Academic Editor: Leandro Pena

Copyright (C) 2015 Mohsen Helmy Selim et al. This is an open access article distributed under the Creative Commons Attribution License, which permits unrestricted use, distribution, and reproduction in any medium, provided the original work is properly cited.

\begin{abstract}
The aim of the present study is to purify L-methioninase from Candida tropicalis 34.19 -fold with $27.98 \%$ recovery after ion exchange chromatography followed by gel filtration. The purified enzyme revealed a single band on SDS-PAGE gel with a molecular weight of $46 \mathrm{KDa}$. Its optimum temperature was 45 to 55 and thermal stability was $55^{\circ} \mathrm{C}$ for $15 \mathrm{~min}$. The enzyme had optimum pH at 6.5 and stability at a pH range of 5.5 to 7.0 for $24 \mathrm{hr}$. The maximum activity was observed with substrate concentration of $30 \mu \mathrm{M}$ and Km was $0.5 \mathrm{mM}$. The enzyme was strongly inhibited by $\mathrm{Cd}^{+2}$ and $\mathrm{Cu}^{+2}$ while it was enhanced by $\mathrm{Na}^{+}, \mathrm{Ni}^{+2}$, and $\mathrm{Mg}^{+2}$ at $10 \mathrm{mM}$ while $\mathrm{Ca}^{+2}$ had slight activation at $20 \mathrm{mM}$. In addition, the potential application of the L-methioninase as an anticancer agent against various types of tumor cell lines is discussed.
\end{abstract}

\section{Introduction}

L-Methioninase is one of few microbial enzymes with high therapeutic value since it was reported as a potent anticancer agent against various types of tumor cell lines: breast, lung, colon, kidney, and glioblastoma [1-3]. Many human cancer cell lines and primary tumors have an absolute requirement for L-methionine, an essential amino acid, to survive and proliferate $[3,4]$. On the other hand, normal cells have the ability to grow on homocysteine, instead of methionine, due to their active methionine synthase [5]. Many tumor cells devoid of the active methionine synthase thus depend on external methionine supplementation of the diet [4]. Consequently, methionine is the main tumor specific target for therapeutic techniques. Thus, therapeutic exploitation of L-methioninase to deplete plasma methionine seems to be a promising strategy [6-9]. Furthermore, the limited distribution of L-methioninase as intracellular enzyme among all microbial pathogens, but not in humans, makes this enzyme a promising drug target for antibacterial, antifungal, and antiprotozoal therapies $[10,11]$.
In light of the importance of L-methioninase as a promising anticancer agent, the present study aims to purify Lmethioninase from Candida tropicalis. Chemical and physical properties of pure enzyme were studied to improve its therapeutic applications. Moreover, the antitumor activity of purified enzyme against different cancer cell lines was evaluated.

\section{Materials and Methods}

2.1. Organism. The organism under study was isolated from Egyptian soil and identified as Candida tropicalis [12].

This strain which is able to grow on Modified Czapek Dox agar plates was cultivated in $250 \mathrm{~mL}$ conical flask containing $30 \mathrm{~mL}$ of Czapek Dox medium [13], enriched with $0.01 \%$ yeast extract. This preculture was incubated for $48 \mathrm{~h}$ at $30^{\circ} \mathrm{C}$ in a controlled environmental shaker (Model G.25, New Brunswick Scientific Co., Edison, USA). The preculture ( $2 \% \mathrm{vol} / \mathrm{vol}$ ) was used to inoculate $250 \mathrm{~mL}$ conical flasks, each containing $30 \mathrm{~mL}$ of modified Czapek Dox medium (main culture) supplemented and enriched with $0.01 \%$ yeast 
extract. Cultures were incubated at $28 \pm 2^{\circ} \mathrm{C}$ for $48 \mathrm{~h}$ with shaking $(150 \mathrm{rpm})$. At the end of the incubation period, yeast cells were harvested by centrifugation ( $5000 \mathrm{rpm}$ for $15 \mathrm{~min}$ ). Cells cake of Candida tropicalis was preliminary treated with n-butanol for releasing highest yield of the enzyme by the method of [12] and assayed for their L-methioninase activities.

2.2. Methioninase Assay. L-Methioninase activity was assayed according to the method of [14] with some modifications using L-methionine as a substrate. Methanethiol produced from substrate reacted with 5.5-dithiobis-2introbenzoic acid added (DTNB; Sigma-Aldrich) to form thionitrobenzoic acid which was detected spectrophotometrically at $412 \mathrm{~nm}$. The assay mixture contained $20 \mathrm{mM}$ L-methionine in $0.05 \mathrm{M}$ potassium phosphate buffer, $\mathrm{pH}$ 7.0, $0.01 \mathrm{mM}$ pyridoxal phosphate, $0.25 \mathrm{mM}$ DTNB, and the enzyme cell-free extract in a final volume of $1 \mathrm{~mL}$. After 10 min of incubation at $45^{\circ} \mathrm{C}$, the increase in absorbance of the developing yellow color was measured at $412 \mathrm{~nm}$. Controls without cell-free extract or with denaturated cellfree extract (cell-free extract was heated at $95^{\circ} \mathrm{C}$ for $30 \mathrm{~min}$ ) were prepared separately. MTL amount was calculated according to a standard curve obtained with sodium methanethiolate. One unit (U) of L-methioninase was expressed as the amount of enzyme that releases $1 \mathrm{mM}$ of methanethiol per minute under optimal assay conditions.

2.3. Protein Concentration. Protein concentration was determined by the method of [15] with bovine serum albumin as standard.

2.4. Partial Purification of L-Methioninase. All purification steps were carried out at $5-10^{\circ} \mathrm{C}$ unless otherwise stated. The buffers used through purification contained $20 \mu \mathrm{M}$ pyridoxal $5^{\prime}$-phosphate for the protection of enzyme activity [16]. The cell-free extract was heated at $60^{\circ} \mathrm{C}$ for different time intervals. After cooling on ice for $1 \mathrm{hr}$. the denatured proteins were removed by centrifugation at $5000 \mathrm{rpm}$ at $4^{\circ} \mathrm{C}$ for $15 \mathrm{~min}$ [17].

\subsection{Purification of L-Methioninase}

(1) Anion Exchange Chromatography on DEAE-Cellulose. This was done according to the method presented by [18]. DEAE-cellulose column $(50 \times 2 \mathrm{~cm})$ equilibrated with the $0.05 \mathrm{M}$ potassium phosphate buffer ( $\mathrm{pH}$ 6.5). The column was washed with the same buffer containing $0.12 \mathrm{M} \mathrm{NaCl}$ until the absorbance at $280 \mathrm{~nm}$ of the elute decreased to less than 0.05 absorbance units. The enzyme-fraction that showed the highest activity from the partial purification step was loaded on the column and then eluted with a linear gradient of $0.15-0.6 \mathrm{M}$ in the same buffer. The flow rate was adjusted to $100 \mathrm{~mL} / \mathrm{hr}$. The enzyme activity and protein content of each elute were determined. The enzyme-active fractions were pooled and dialyzed against distilled water at $4^{\circ} \mathrm{C}$. The enzyme purity was checked by polyacrylamide gel electrophoresis.
(2) Sephadex G-200 Chromatography. This was done according to the method presented by [19]. A Sephadex G-200 resin was soaked in $0.05 \mathrm{M}$ sodium citrate buffer $(\mathrm{pH} 6.5)$ and allowed to swell. The swollen beads were poured down into chromatographic column $(50 \times 2 \mathrm{~cm})$ and left to settle to a constant height of $45 \mathrm{~cm}$ without pressure. The enzymeactive sample from the DEAE-cellulose column was applied to a column of Sephadex G-200 equilibrated and eluted with $0.05 \mathrm{M}$ sodium citrate buffer $(\mathrm{pH} 6.5)$ at a flow rate of $30 \mathrm{~mL} / \mathrm{hr}$. Eliot ( $5 \mathrm{~mL}$ fractions) was collected separately for the measurement of enzyme activity and protein content. Enzyme-active fractions were pooled and lyophilized. The enzyme purity was checked using SDS-polyacrylamide gel electrophoresis.

2.6. Determination of Molecular Weight by Gel Electrophoresis. The homogeneity of purified L-methioninase was checked using dissociating polyacrylamide gel electrophoresis (SDSPAGE) and was carried out according to a protocol proposed by [20].

2.7. Amino Acid Analysis. Amino acid content was determined as described in [21].

2.8. Some Biochemical Properties of L-Methioninase Effect of Temperature on the Activity and Stability of L-Methioninase. The effect of reaction temperature on L-methioninase activity was determined by incubating the reaction mixture at different temperatures ranging from 30 to $60^{\circ} \mathrm{C}$ in $0.05 \mathrm{M}$ sodium citrate buffer. The thermal stability of the purified enzyme was determined by preincubating the enzyme solution for up to $1 \mathrm{~h}$ at various temperatures $\left(40,45,50,55,60,65\right.$, and $\left.70^{\circ} \mathrm{C}\right)$ in the absence of substrate. At different times (15-60 min), aliquots were removed and cooled and the residual activity was measured by the standard assay method as previously mentioned.

2.9. Effect of $p H$ on the Activity and Stability of $L$ Methioninase. The optimum $\mathrm{pH}$ for L-methioninase activity was determined using $0.05 \mathrm{M}$ sodium citrate $(\mathrm{pH} 4.0-7.0$ ) and $0.05 \mathrm{M}$ potassium phosphate ( $\mathrm{pH}$ 6.5-8.0) buffers. After incubating each reaction at $45^{\circ} \mathrm{C}$ for $10 \mathrm{~min}$, enzymatic activity was detected. The $\mathrm{pH}$ stability of the enzyme was determined by preincubating the enzyme solution at different $\mathrm{pH}$ values ranging from 4.0 to 8.0 with $0.02 \mathrm{mM}$ PLP for $2 \mathrm{~h}$ at $4^{\circ} \mathrm{C}$. At the end of preincubation time, the $\mathrm{pH}$ value of enzyme solution was readjusted to $\mathrm{pH} 6.5$ and then residual enzyme activity was assayed by the standard method.

2.10. Effect of Inhibitors on L-Methioninase Activity. Compounds tested for their inhibitory effects included iodoacetate, glycine, phenylmethylsulfonyl fluoride (PMSF), Tris, and EDTA. The inhibitory effect of these compounds on enzyme activity was assessed by incubating enzyme solution with 1 and $10 \mathrm{mM}$ concentrations of each compound for $20 \mathrm{~min}$ before addition of substrate. After preincubation time, enzymatic activity was determined under optimal assay conditions. 
2.11. Measurement of Potential Cytotoxicity by SRA Assay. Potential cytotoxicity of L-methioninase was tested using the method of [22].

\section{Results and Discussion}

3.1. Purification of L-Methioninase from Candida tropicalis and Molecular Weight Determination. In the preceding part of this work, a crude enzyme preparation (CFE) was obtained from Candida tropicalis cells grown under optimized growth conditions as mentioned before. It was necessary to investigate and characterize such an enzyme activity. Therefore, in this section, a study on the purification of intracellular L-methioninase from Candida tropicalis was carried out. Furthermore, some physical and biochemical properties of pure enzyme were investigated.

Equal portions of CFE were purified by heating at $55^{\circ} \mathrm{C}$ and $60^{\circ} \mathrm{C}$ for different time intervals-10, 20, and $30 \mathrm{~min}$. After cooling CFE in an ice bath followed by centrifugation at $5^{\circ} \mathrm{C}$, three fractions were obtained for each temperature. Data presented in Table 1 indicate that following heat treatment at $60^{\circ} \mathrm{C}$ for 10 min gave the highest enzyme activity and enzyme recovery. Therefore, crude enzyme preparation was subjected to heat treatment at $60^{\circ} \mathrm{C}$ for $10 \mathrm{~min}$ followed by a two-step chromatographic technique-ion exchange chromatography followed by gel filtration chromatography; see Data Table 1 and Figures 1 and 2.

Complete purification scheme of L-methioninase was achieved by heat treatment followed by anion exchange chromatography (DEAE-cellulose) and gel filtration chromatography (Sephadex G-100). Following heat treatment at $60^{\circ} \mathrm{C}$ for $10 \mathrm{~min}$, the activity increased 1.5 -fold compared to the crude enzyme. Furthermore, this step also decreased the overall protein content in the precipitation fraction containing the highest enzyme recovery. A successive set of purification steps was required to achieve a higher purification fold. The obtained data indicate that the purification of L-methioninase on DEAE-cellulose revealed purification fold of 24.73 with $61.4 \%$ yield. From the overall purification process, it was found that the preparation of pure enzyme can be carried out in just three purification steps, with purification fold of 43.19 and $27.98 \%$ enzyme recovery. These results are higher than those obtained by [23] for L-methioninase purified from Brevibacterium linens in five purification steps, including ammonium sulfate precipitation followed by several chromatographic procedures. In addition, [24] purified L-methioninase with $21 \%$ yield from Citrobacter freundii by heat treatment at $60^{\circ} \mathrm{C}$ followed by separation on DEAE-cellulose column and Sephacryl S200HR column. Furthermore, L-methioninase was purified to electrophoretic homogeneity from Aspergillus flavipes 12.1fold using ammonium sulfate precipitation followed by anion exchange and gel-filtration chromatography [25]. On the other hand, Figure 3 shows the electrophoretogram of the crude and purified L-methioninase from Candida tropicalis as determined using SDSPAGE. The molecular weight of the purified enzyme was estimated to be 46 . In accordance with our results, the appearance of L-methionine as a single band is clear when the gel was electrophoresed under denaturing

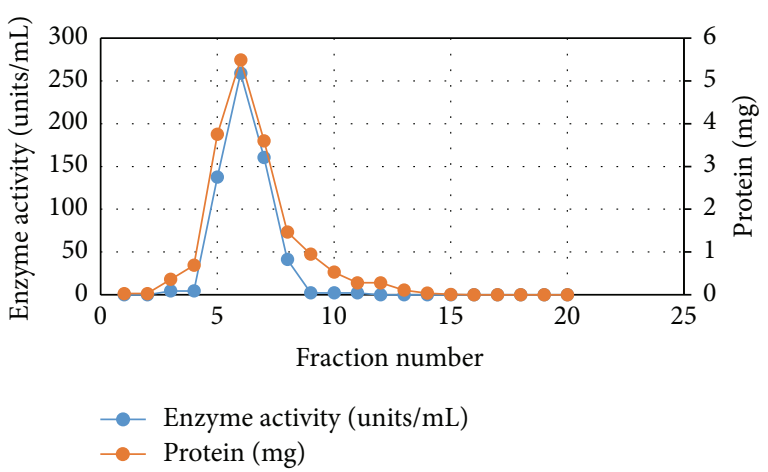

Figure 1: Purification of L-methioninase using DEAE-cellulose.

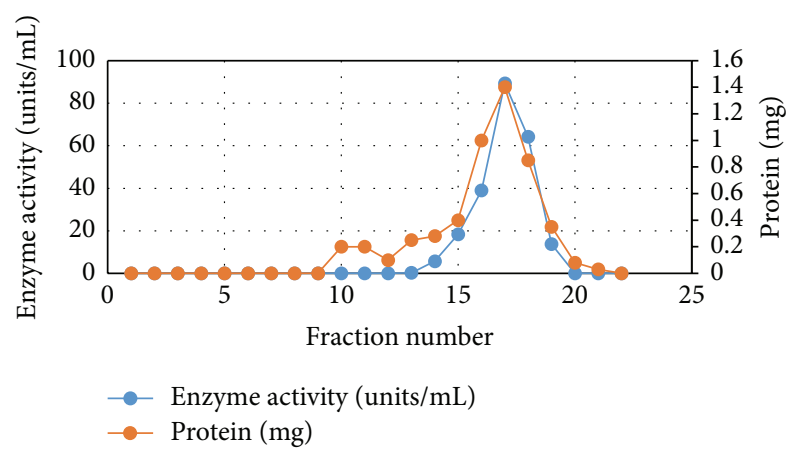

FIgure 2: Purification of L-methioninase enzyme using Sephadex G-200.

conditions ensuring the homogeneity and purity of the enzyme. The molecular mass of the purified enzyme was determined during the final stage of purification and it was estimated to be approximately $46 \mathrm{kDa}$. In accordance with our results, the purified enzyme is similar to other Lmethioninases purified from different sources. As reviewed earlier, the molecular weight of L-methioninase purified from bacterial and fungal sources could range between 43 and $48 \mathrm{kDa}[26,27]$. In addition, [23] reported that the total molecular mass of purified L-methioninase from Brevibacterium linens was $170 \mathrm{kDa}$, with four identical subunits, each one of $46 \mathrm{kDa}$. Also, the molecular weight of L-methioninase purified from Citrobacter freundii [28] was found to range from 43.0 to $45.0 \mathrm{kDa}$ per subunit.

3.2. Amino Acid Analysis. The complete amino acid content of the purified L-methioninase enzyme was determined by analysis of protein using LC3000 amino acid analyzer (Eppendorf, Biotronik, Germany). Data not shown clearly indicate that the enzyme has high concentrations of glutamic acid followed by histidine, aspartic acid, arginine, and lysine. Furthermore, considerable concentrations of alanine, methionine, valine, serine, and isoleucine were also detected. In this respect, the amino acid composition of pyridoxal phosphate L-methioninase is clearly differentiated among various microorganisms. Reference [29] mentioned that amino acid composition of $P$. putida $\mathrm{L}$-methioninase revealed that residues tyrosine, arginine, proline, leucine, glutamic 
TABLE 1: Purifications steps, purification folds, and recovery yields of L-methioninase.

\begin{tabular}{|c|c|c|c|c|c|}
\hline Purification step & $\begin{array}{l}\text { Total protein } \\
(\mathrm{mg}) \pm \mathrm{SD}\end{array}$ & $\begin{array}{l}\text { Total activity } \\
\text { (units) } \pm \text { SD }\end{array}$ & $\begin{array}{c}\text { Specific activity } \\
\text { (U/mg protein }) \pm S D\end{array}$ & $\begin{array}{c}\text { Enzyme recovery } \\
(\%)\end{array}$ & Purification fold \\
\hline Crude enzyme & $3469.2 \pm 89$ & $5243.18 \pm 78$ & $1.5 \pm 0.2$ & 100 & 1 \\
\hline $\begin{array}{l}\text { Heat treatment at } \\
60^{\circ} \mathrm{C} \text { for } 10 \mathrm{~min}\end{array}$ & $2360.9 \pm 94$ & $4876.5 \pm 70$ & $2.06 \pm 0.1$ & 93.0 & 1.37 \\
\hline $\begin{array}{l}\text { DEAE cellulose } \\
\text { fractions }(3-11)\end{array}$ & $87.0 \pm 21$ & $3219.6 \pm 45$ & $37.1 \pm 11$ & 61.4 & 24.73 \\
\hline $\begin{array}{l}\text { Sephadex G-100 } \\
\text { fractions }(14-20)\end{array}$ & $22.65 \pm 10$ & $1467.41 \pm 38$ & $64.78 \pm 7$ & 27.98 & 43.19 \\
\hline
\end{tabular}

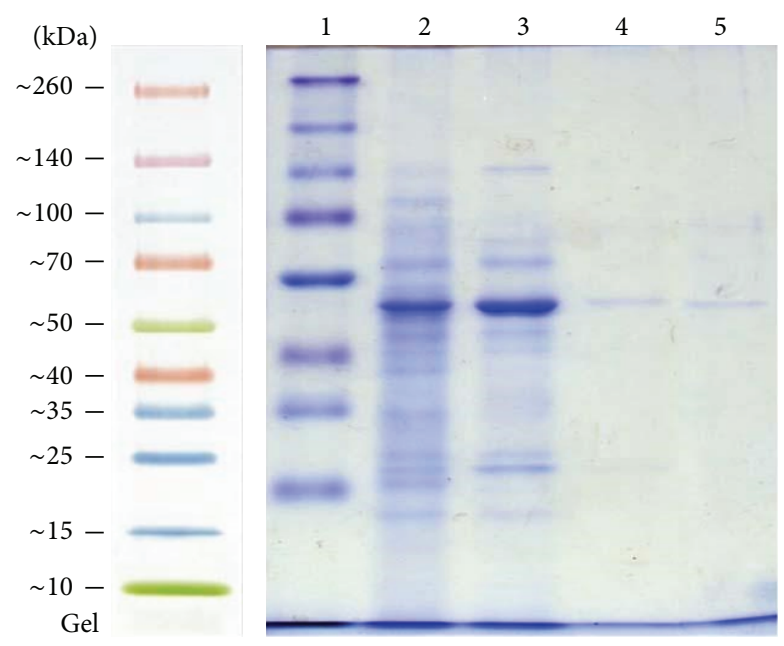

FIGURE 3: SDS-PAGE analysis of different stages during the purification of L-methioninase from C. tropicalis. Lane 1, molecular weight marker proteins; lane 2, crude enzyme preparation; lane 3, heat treatment fraction; lane 4, DEAE-cellulose; lane 5, Sephadex G-200. Approximate molecular mass in kilodaltons are indicated on the left.

acid, glycine, methionine, isoleucine, aspartic acid, histidine, lysine, and serine are commonly conserved among different L-methioninases. Reference [30] reported that several amino acid residues such as tyrosine, arginine, cysteine, lysine, and aspartic acid form active sites of Pseudomonas putida L-methioninase. However, L-methioninase from Brevibacterium linens does not have the cysteine residue and it was substituted by glycine [11, 31]. Recently it was reported that methionine, aspartic acid, histidine, and glycine were found among all the pyridoxal-phosphate dependent enzymes [32].

3.3. Physicochemical Properties of Purified L-Methionine. In the following part of this study, several experiments were carried out to investigate and characterize the activity of the purified enzyme in the hope of revealing some of its physiochemical properties that might be of significance in medical applications.

\section{Time Course and Profiles of L-Methionine Reaction}

Time course and profiles of L-methionine reaction (data not shown) indicate that the rate of methanethiol release increased as the reaction time increased up to $20 \mathrm{~min}$; thereafter no additional hydrolysis products were liberated. Similar results were recorded for L-methioninase from Pseudomonas putida $[17,26,33]$ where the authors studied the time course of Pseudomonas putida L-methionine $\gamma$-lyase reaction at $37^{\circ} \mathrm{C}$ for different times. They mentioned that the enzyme activity increased as the incubation time increased and the nonlinear increase of enzyme activity is caused by the multifunctional catalysis of L-methionine. In addition, [34] estimated Lmethionine in cell-free extracts of cheese-ripening yeasts after $30 \mathrm{~min}$ of reaction.

4.1. Effect of Temperature on L-Methioninase Activity and Stability. The optimum temperature for L-methioninase activity was determined. The temperature profile of L-methioninase was shown in Figure 4.

The optimum temperature of the enzyme activity was $45^{\circ} \mathrm{C}$. Moreover, at $60^{\circ} \mathrm{C}$, the enzyme retained about $96.1 \%$ of its original activity. At higher temperatures, a gradual decrease in enzyme activity was observed. This outcome may be explained by the fact that the temperature increases the reaction velocity and also affects the rate of enzyme destruction, producing a gradual fall in the concentration of active enzyme. In this finding, the optimum temperature for C. tropicalis L-methioninase was slightly higher than that reported for L-methioninase purified from cheese lactic acid bacteria, which was found to be $37^{\circ} \mathrm{C}$ [35]. Also, $37^{\circ} \mathrm{C}$ was the optimum temperature for L-methioninase purified from Pseudomonas putida. Moreover, [16] found that the activity of Clostridium sporogenes L-methioninase increased slightly when heated for $15 \mathrm{~min}$ at $50^{\circ} \mathrm{C}$ or for $10 \mathrm{~min}$ at $60^{\circ} \mathrm{C}$ with a rapid loss of activity after further heating at $60^{\circ} \mathrm{C}$. In addition, [25] reported that L-methioninase purified from Aspergillus flavipes exhibited maximum activity at $35^{\circ} \mathrm{C}$ followed by a gradual decrease until it retained only $48.4 \%$ of its activity at $60^{\circ} \mathrm{C}$. However, L-methioninase of Brevibacterium linens showed optimum activity at $25^{\circ} \mathrm{C}$ [7].

Regarding the thermal stability of L-methioninase (Data Figure 5), there was a general agreement between optimum reaction temperatures lying in the range $45-55^{\circ} \mathrm{C}$ and the thermal stability of the enzyme at $55^{\circ} \mathrm{C}$ for $15 \mathrm{~min}$. Furthermore, after heating purified enzyme at 65 and $70^{\circ} \mathrm{C}$ for $15 \mathrm{~min}$, the enzyme still retained about $81 \%$ of its original activity. These results indicate that L-methioninase purified from C. tropicalis is a thermostable enzyme. In agreement with our results, [36] reported that L-methionine $\gamma$-lyase purified 


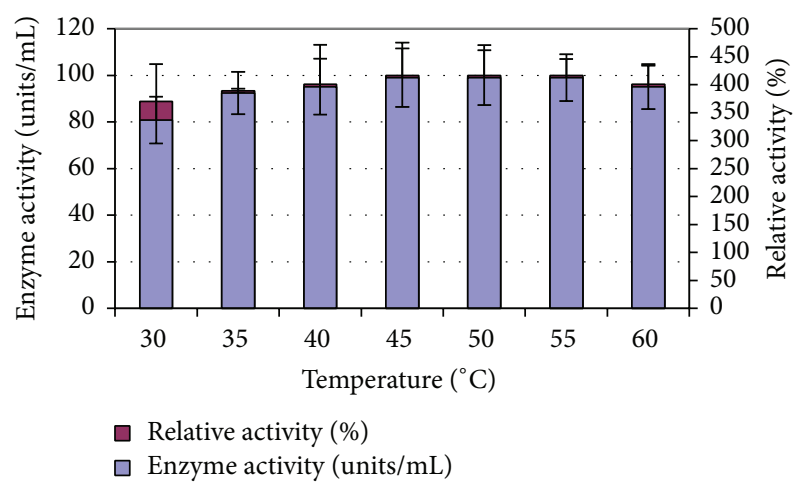

FIGURE 4: Effect of temperature on L-methioninase activity.

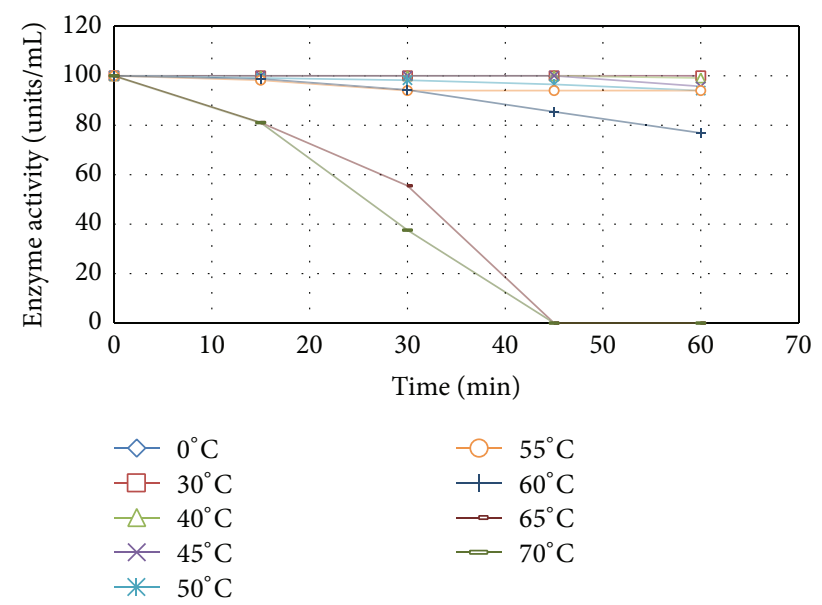

FIGURE 5: Heat inactivation kinetics of the pure L-methioninase activity.

from Aeromonas sp. retained $82 \%$ of its original activity after incubation at $60^{\circ} \mathrm{C}$ for $5 \mathrm{~min}$. Similarly, L-methionine $\gamma$ lyase of Brevibacterium linens NSDO739 was also stable to high temperatures as reported by [37]. On the contrary, the authors of [23] studied thermal stability of L-methionine $\gamma$ lyase purified from $B$. linens BL2 and they observed that the enzyme was labile at temperatures greater than $30^{\circ} \mathrm{C}$.

\subsection{Effect of Different pH Values on L-Methioninase Activity.} The optimum $\mathrm{pH}$ for L-methioninase activity was determined by measuring activity at different $\mathrm{pH}$ values using $50 \mathrm{mM}$ sodium citrate buffer $(\mathrm{pH} 4.0-6.5)$ and $50 \mathrm{mM}$ potassium phosphate ( $\mathrm{pH} 6.0-8.0$ ). The enzyme activity was assayed by standard method and the results are presented in Table 2 . The enzymes are generally active only over a limited range of $\mathrm{pH}$ values and the activity of most enzymes shows a maximum at definite $\mathrm{pH}$ value, that is, the optimal $\mathrm{pH}$ value. In this respect, the activity of L-methioninase purified from C. tropicalis was favored by neutral $\mathrm{pH}$ values with optimum $\mathrm{pH}$ at 6.5 and began to decrease with increasing $\mathrm{pH}$ value. This may be attributed to the fact that enzymes are proteins and hence any changes in the $\mathrm{pH}$ values can profoundly affect the ionic character of the amino acid or carboxylic groups and can therefore markedly affect the catalytic site and
TABLE 2: Effect of different $\mathrm{pH}$ values on the purified Lmethioninase activity.

\begin{tabular}{lccc}
\hline $\mathrm{pH}$ & $\begin{array}{c}\text { Type of } \\
\text { buffer }\end{array}$ & $\begin{array}{c}\text { Enzyme activity } \\
(\mathrm{U} / \mathrm{ml})\end{array}$ & Relative activity (\%) \\
\hline 4.0 & $\mathrm{~A}$ & $128.33 \pm 55$ & 38.35 \\
& $\mathrm{~B}$ & - & - \\
\hline 5.0 & $\mathrm{~A}$ & $252.10 \pm 60$ & 75.35 \\
& $\mathrm{~B}$ & - & - \\
\hline \multirow{2}{*}{5.5} & $\mathrm{~A}$ & $274.94 \pm 74$ & 82.17 \\
& $\mathrm{~B}$ & - & - \\
\hline \multirow{2}{*}{6.0} & $\mathrm{~A}$ & $302.50 \pm 69$ & 90.41 \\
& $\mathrm{~B}$ & $260.34 \pm 80$ & 90.92 \\
\hline \multirow{2}{*}{6.5} & $\mathrm{~A}$ & $334.57 \pm 88$ & 100 \\
& $\mathrm{~B}$ & $286.35 \pm 82$ & 100 \\
\hline 7.0 & $\mathrm{~A}$ & - & - \\
& $\mathrm{B}$ & $260.79 \pm 53$ & 91.10 \\
\hline 7.5 & $\mathrm{~A}$ & - & - \\
& $\mathrm{B}$ & $245.35 \pm 82$ & - \\
\hline \multirow{2}{*}{8.0} & $\mathrm{~A}$ & - & 79.63 \\
\hline $\mathrm{A}$ & $\mathrm{B}$ & $228.0 \pm 75$ & \\
\hline
\end{tabular}

A: sodium citrate buffer; B: potassium phosphate buffer.

conformation of an enzyme. In addition, the affinity between the enzyme and its substrate may also be affected by the $\mathrm{pH}$ value of the reaction and the enzyme may not be saturated with substrate at $\mathrm{pH}$ values below or above the optimum. On the other hand, it could be noticed that the sodium citrate buffer $(0.075 \mathrm{M})$ was more suitable than potassium phosphate buffer to achieve the highest enzyme activity (data not shown). This result proved that the presence of sodium ions was necessary to enhance enzyme activity. In this finding, neutral to slightly alkaline $\mathrm{pH}$ values were reported for L-methioninase purified from Aspergillus flavipes [25]. On the other hand, the optimal pH for bacterial L-methioninase has been reported to proceed at alkaline range. Reference [38] reported an optimum $\mathrm{pH} 7.2$ for L-methioninase purified from Pseudomonas ovalis.

4.3. pH Stability. In this experiment, enzyme solutions were stored at $\mathrm{pH}$ values ranging from 48 to $24 \mathrm{~h}$ at $4^{\circ} \mathrm{C}$. Thereafter, the $\mathrm{pH}$ value of the enzyme solution was readjusted to $\mathrm{pH} 6.5$ and added to the reaction mixture containing the substrate and the enzyme activity was then determined. The results recorded in Figure 6 indicated that the enzyme kept its activity at $\mathrm{pH} 5.5$ up to $\mathrm{pH} 7.5$. A slight decrease in the enzyme activity was observed at $\mathrm{pH} 8.0$ while at $\mathrm{pH} 5.0$ the enzyme retained about $81 \%$ of its initial activity.

Furthermore, at $\mathrm{pH}$ 8.0, the enzyme retained over $94 \%$ of its activity. The lower stability of the enzyme at higher or lower $\mathrm{pH}$ values may be caused by denaturation and hence inactivation of the enzyme protein. It is worth mentioning that the stability range of the enzyme which is higher than the $\mathrm{pH}$ of blood (7.4) ensures the therapeutic value of $\mathrm{L}$ methioninase purified from $C$. tropicalis. The similar $\mathrm{pH}$ 


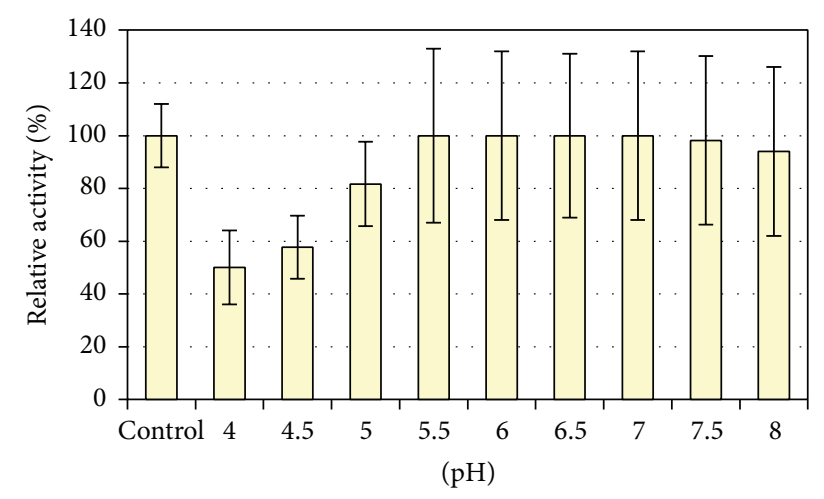

${ }^{*}$ Enzyme stored for $2 \mathrm{hr}$ at $4^{\circ} \mathrm{C}$ in sodium citrate buffer

FIGURE 6: Determination of $\mathrm{pH}$ stability of pure L-methioninase activity.

stability curve was obtained for L-methioninase purified from Pseudomonas putida (42.31). Additionally, the authors of [39] studied $\mathrm{pH}$ stability of L-methionine $\gamma$-lyase obtained from Brevibacterium linens. They found that the enzyme was stable at $\mathrm{pH}$ ranging from 6.0 to 8.0 for $24 \mathrm{~h}$. At $\mathrm{pH} 5.5$, the enzyme retained over $20 \%$ of its activity and at $\mathrm{pH} 4.0$ it became inactivated.

4.4. Substrate Specificity of Purified L-Methioninase. This experiment was designed to evaluate the specificity of the purified L-methioninase towards various substrates. Equal amounts $(20 \mathrm{mM})$ of various substrates, namely, Lmethionine, DL-methionine, cysteine, and cysteine, were added separately to the reaction mixture and incubated under optimum assay conditions. The data obtained are presented as relative activities in Figure 7. It was found that the enzyme showed the highest affinity towards L-methionine as a standard substrate. Furthermore, cysteine was degraded to 35\% of the level of activity of L-methionine. On the other hand, the enzyme activities towards DL-methionine and cysteine were less than $50 \%$ and $59 \%$, respectively, compared to that towards L-methionine. Studies on the substrate specificity of C. tropicalis L-methioninase revealed that the enzyme had a relative activity towards various amino acids. The enzyme exhibited high specificity for L-methionine. Additionally, Lcysteine and DL-methionine serve as effective substrates. In agreement with our results, the author of [25] examined the substrate specificity of L-methioninase purified from Aspergillus flavipes. The author reported that the enzyme had relative catalytic activity towards different amino acids. The enzyme exhibited high specificity for L-methionine. Furthermore, the enzyme was significantly more active on Lcysteine than on L-cystine as substrate. On the other hand, C. tropicalis L-methioninase is distinctly different from a bacterial enzyme in its substrate specificity where all purified bacterial L-methioninases have higher affinity towards Lcysteine compared to L-methionine [24, 40, 41]. However, [18] mentioned that L-methionine is the preferred substrate for L-methioninase purified from $P$. putida. In addition, several derivatives of L-methionine and L-cysteine serve as effective substrates.

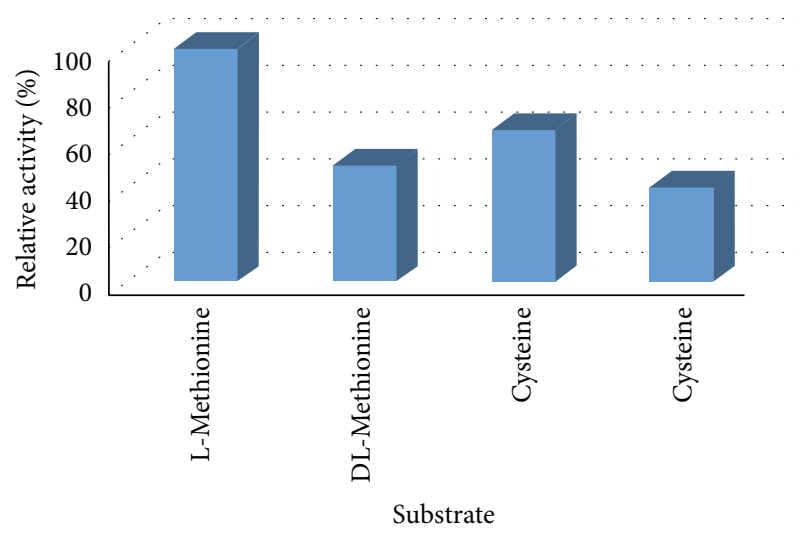

FIGURE 7: Substrate specificity of purified L-methioninase determination of kinetic parameters.

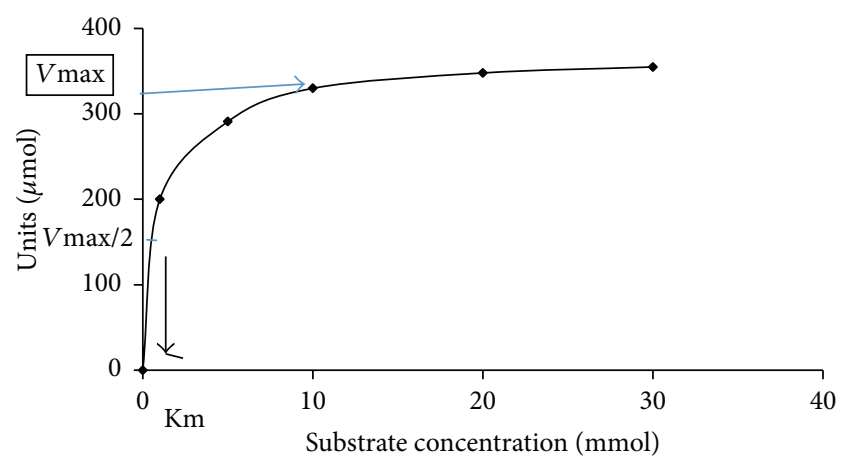

FIGURE 8: Saturation kinetics of the L-methioninase activity with the substrate.

In this experiment, the kinetic parameters such as Michaelis-Menten constant $(\mathrm{Km})$ and maximum velocity $\left(V_{\max }\right)$ of purified L-methioninase were determined by incubating the enzyme with different concentrations of Lmethionine as a substrate in the range of $1 \mu \mathrm{M}$ to $40 \mu \mathrm{M}$ under optimum assay conditions. The apparent $\mathrm{Km}$ of purified enzyme was calculated from a Lineweaver-Burk plot. The Km value of $\mathrm{L}$-methioninase was found to be $0.5 \mathrm{mM}$ as shown in Figures 8 and 9.

Results obtained in this respect show that the enzyme showed maximal activity at a substrate level of $30 \mathrm{mM}$ followed by a slight decrease at higher concentrations. This indicates that the active center of the enzyme became saturated with its substrate at concentrations above $30 \mathrm{mM}$. Moreover, the apparent $\mathrm{Km}$ of L-methioninase was found to be $0.5 \mathrm{mM}$ indicating high affinity of C. tropicalis Lmethioninase to its substrate and sustain its high therapeutic value. In this finding, different $\mathrm{Km}$ values were obtained for L-methioninase purified from various microbial sources. In this respect, L-methioninase isolated from Pseudomonas putida was reported to exhibit a $\mathrm{Km}$ of $1 \mathrm{Mm}$ [42], whereas L-methioninase from Citrobacter freundii showed a $\mathrm{Km}$ of $0.7 \mathrm{mM}$ [43]. In addition, the $\mathrm{Km}$ value for Brevibacterium sp. L-methioninase [23] is approximately six times higher than that observed for Citrobacter intermedius [44] revealing 


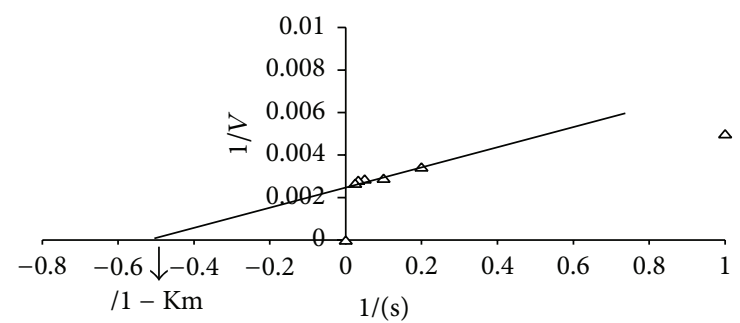

Figure 9: Line weaver Burk plot of the of initial velocities and substrate concentration.

the highest specificity of the latter to L-methionine. Furthermore, it was reported that the specificity of fungal Lmethioninase was higher than that observed for bacterial enzymes as clearly observed from the values of $\mathrm{Km}$ for L-methionine. L-Methioninase from Clostridium sporogenes appears to have very low specificity to L-methionine (Km value of $90 \mathrm{mM}$ ), suggesting its low efficiency as antitumor agent [16]. Interestingly, L-methioninase from Aspergillus flavipes displayed higher affinity to L-methionine, ensuring its higher therapeutic value [25].

4.5. Effect of Different Metal Ions and Inhibitors on LMethioninase Activity. Metal ions may serve as activators or inhibitors in numerous enzymatically catalyzed reactions. Therefore, the effect of some metal ion on L-methioninase activity was investigated (Figures 10 and 11). The results obtained in this respect indicate that $\mathrm{Na}^{+}$act as a potent activator, where the enzyme activity was significantly increased to more than $200 \%$ of the original activity at a final concentration of $20 \mathrm{mM}$. Moreover, $\mathrm{Mg}^{+2}, \mathrm{~K}^{+}$, and $\mathrm{Ni}^{+2}$ had an activating effect on enzyme activity. On the other hand, the enzyme activity was inhibited in the presence of $\mathrm{Cr}^{+2}$, $\mathrm{Zn}^{+2}, \mathrm{Fe}^{+2}, \mathrm{Ba}^{+}$, and $\mathrm{Co}^{+2}$. While $\mathrm{Cd}^{+2}$ and $\mathrm{Cu}^{+2}$ inhibited the enzyme activity completely at a final concentration of $10 \mathrm{Mm}$. It is worth mentioning that the inhibition of enzyme activity in the presence of $\mathrm{Cu}^{+2}$ indicated that the active site of the enzyme involved -SH group, where $\mathrm{Cu}^{+2}$ are known to inhibit $-\mathrm{SH}$ enzymes by catalyzing the oxidation of $-\mathrm{SH}$ to disulphide. Furthermore, significant inhibition of L-methioninase activity by EDTA, a metal ion chelator, indicates that this enzyme is a metalloenzyme. Additionally, the enzyme was completely inactivated by a thiol reducing agent such as iodoacetate. The complete inhibition of Lmethioninase with this agent provides evidence for the presence of $-\mathrm{SH}$ group in the active sites of enzyme. In this finding, [45] mentioned that L-methioninase activity of Brevibacterium linens was stimulated to by $\mathrm{Na}^{+}$and $\mathrm{K}^{+}$and strongly inhibited by $\mathrm{Zn}^{+2}, \mathrm{Mn}^{+2}$, and $\mathrm{Cu}^{+2}$. In addition, the authors of [23] studied the effect of some inhibitors on $B$. linens L-methioninase activity. They found that iodoacetate inhibited enzyme activity at $10 \mathrm{mM}$ while metal chelating agents did not influence enzyme activity. On the other hand, the activity of L-methioninase of Lactococcus lactis [28] and Aspergillus flavipes [46] was significantly reduced by sulfhydryl reagents including iodoacetic acid and 2mercaptoethanol. Moreover, the inhibition of enzyme activity

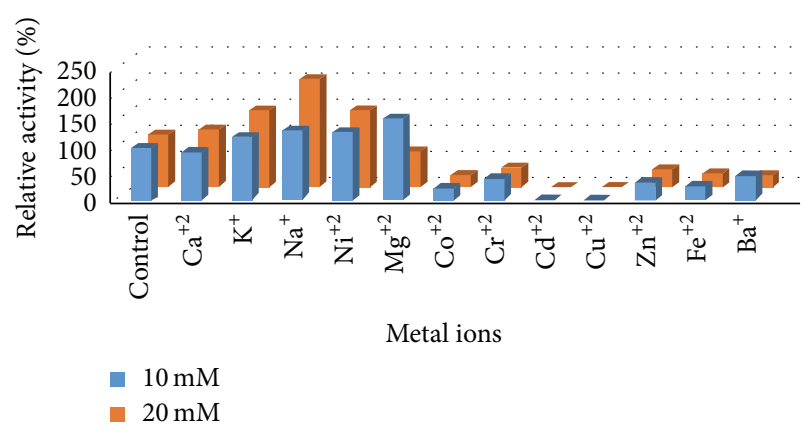

FIGURE 10: Effect of different metal ions on L-methioninase activity.

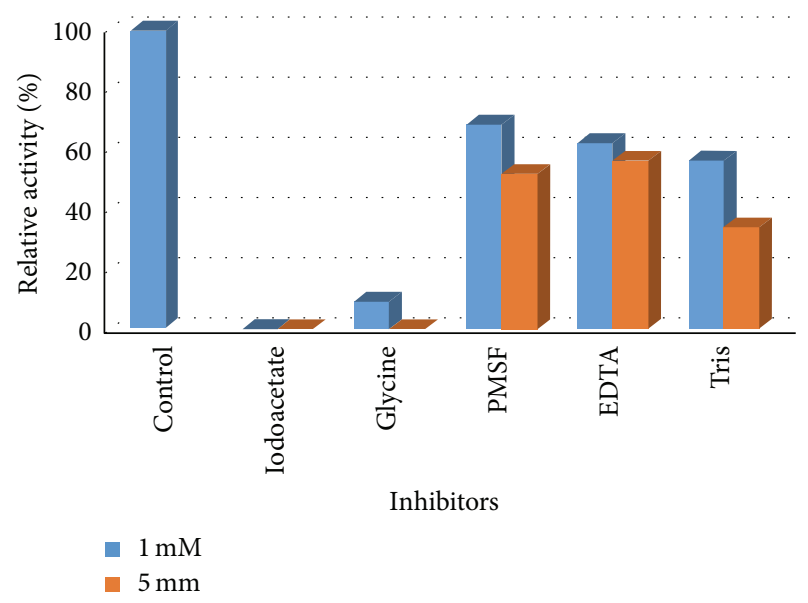

FIGURE 11: Effect of different inhibitors on L-methioninase activity.

by glycine, Tris, and PMSF was also reported by [38]. It was reported that amino group of Tris molecule probably interacts with the enzyme associated PLP through a hydrogen bond and would therefore affect the enzyme activity [47].

4.6. Effect of Pyridoxal 5'-Phosphate Concentration on LMethioninase. This experiment was carried out to detect the optimal concentration of PLP. The enzyme activity was assayed in standard reaction mixture supplemented with different concentrations of PLP ranging from 100 to $500 \mathrm{mM}$ (data not shown). It is clear that L-methioninase activity increased gradually with the increase of PLP concentration up to $300 \mathrm{mM}$ where the highest enzyme activity was obtained.

4.7. Cytotoxicity Test of L-Methioninase on Different Human Cancer Cell Lines. Cell-free extract containing high Lmethioninase activity was obtained from $C$. tropicalis cells grown under optimum cultural and nutritional conditions. Therapeutically useful L-methioninase requires not only sufficient activity, but also an efficient method of purification [17]. Therefore, further studies were needed to purify the crude L-methioninase with the highest specific activity and good yield; see Figures 12 and 13 .

In vitro antitumor efficiency studies of Candida tropicalis L-methioninase on growth of three human tumor cell lines, 


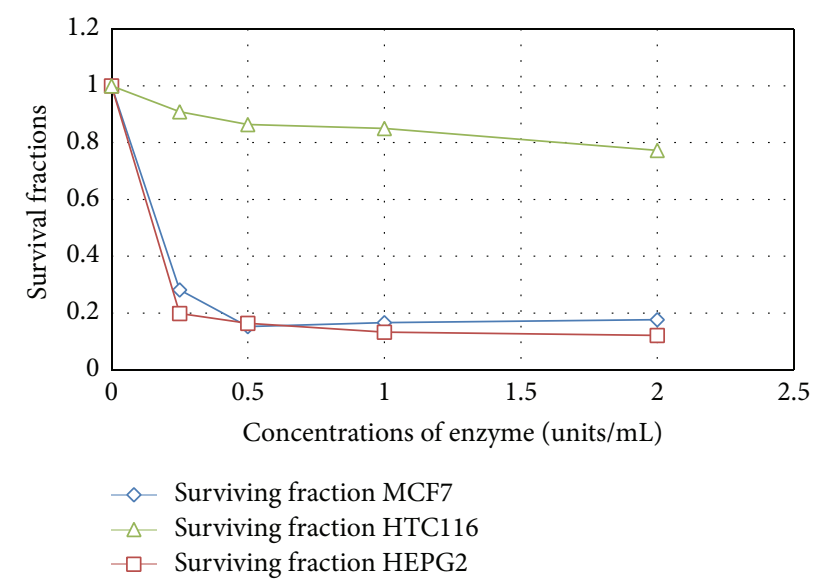

FIGURE 12: In vitro cytotoxic effect of partial purified L-methioninase on liver (HEPG2), breast (MCF7), and colon (HCT 116) cancer cell lines.

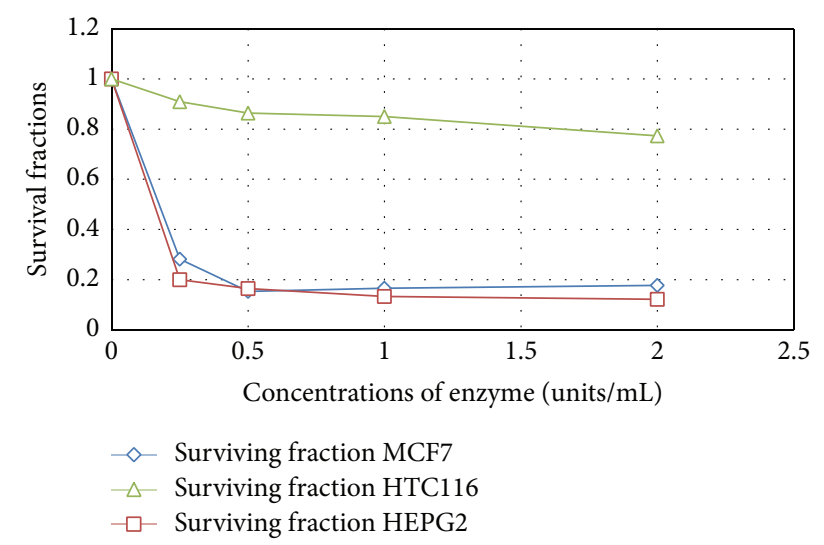

FIGURE 13: In vitro cytotoxic effect of pure L-methioninase on liver (HEPG2), breast (MCF7), and colon (HCT 116) cancer cell lines.

namely, liver (HEPG2), breast (MCF7), and colon (HCT 116), proved that the enzyme has strong antitumor activity against liver and breast cancer cell lines and this effect is concentration dependent. Moreover, sensitivity of cancer cells to enzymatic methionine depletion differed among cell lines; the breast cancer cell line was more sensitive $\left(\mathrm{IC}_{50}\right.$ of $0.13 \mathrm{U} / \mathrm{mL}$ ) than liver cancer cell line $\left(\mathrm{IC}_{50} 0.2 \mathrm{U} / \mathrm{mL}\right)$. The efficiency of L-methioninase against various cell lines was reported by many authors [2, 22, 48, 49]. In addition, the authors of [33] tested the sensitivity of cancer cell lines to L-methioninase, produced by Pseudomonas putida. They found that leukemia cell lines tested are more sensitive to L-methioninase than solid tumor cell lines. The $\mathrm{IC}_{50}$ in leukemia cell lines was less than $0.5 \mathrm{U} / \mathrm{mL}$. On the other hand, solid tumor cell lines demonstrated variable sensitivity. The $\mathrm{IC}_{50}$ of lung cancer cell line was $0.8 \mathrm{U} / \mathrm{mL}$, while the glioma cell line T98G and the breast cancer cell MCF-7 line were less sensitive to L-methioninase, with $\mathrm{IC}_{50}$ values of $1.5 \mathrm{U} / \mathrm{mL}$. Furthermore, the authors of [27] evaluate the antitumor efficiency of Aspergillus flavipes L-methioninase against various human cell lines in vitro. They mentioned that the enzyme showed a powerful activity against prostate
(PC3), liver (HEPG2), and breast (MCF7) cancers, with $\mathrm{IC}_{50} 0.001 \mathrm{U} / \mathrm{mL}, 0.26 \mathrm{U} / \mathrm{mL}$, and $0.37 \mathrm{U} / \mathrm{mL}$, respectively. Furthermore, our data of Candida tropicalis L-methioninase indicated that this enzyme was more effective against breast cancer than that produced by Pseudomonas putida [33] and Aspergillus flavipes [27].

\section{Conclusion}

This study demonstrated the ability of Candida tropicalis to produce L-methioninase, which has different practical applications, especially in cancer therapy. The whole production process was comprehensively optimized and the enzyme was purified to homogeneity. The purified enzyme was stable at a wide range of $\mathrm{pH}$ and temperature. It has high affinity to its substrate exhibiting a low $\mathrm{Km}$ of $0.5 \mathrm{mM}$ which confirmed its high therapeutic value. Moreover, the enzyme has been found to possess significant antitumor activity against different cell lines in vitro. Therefore, we can say that L-methioninase treatment will provide a novel way for cancer therapy.

Until now, no publications have been reported on the purification of L-methioninase from yeast. This is the first study to include purification and characterization of Lmethioninase from yeast.

\section{Conflict of Interests}

The authors declare that there is no conflict of interests regarding the publication of this paper.

\section{References}

[1] F. Breillout, E. Antoine, and M. F. Poupon, "Methionine dependency of malignant tumors: a possible approach for therapy," Journal of the National Cancer Institute, vol. 82, no. 20, pp. 1628$1632,1990$.

[2] Y. Tan, M. Xu, X.-Z. Tan et al., "Overexpression and largescale production of recombinant L-methionine- $\alpha$-deamino- $\gamma$ mercaptomethane-lyase for novel anticancer therapy," Protein Expression and Purification, vol. 9, no. 2, pp. 233-245, 1997.

[3] M. E. Anderson, "Glutathione: an overview of biosynthesis and modulation," Chemico-Biological Interactions, vol. 111-112, pp. 114, 1998.

[4] R. M. Hoffman, "Altered methionine metabolism, DNA methylation and oncogene expression in carcinogenesis: a review and synthesis," Biochimica et Biophysica Acta-Reviews on Cancer, vol. 738, no. 1-2, pp. 49-87, 1984.

[5] J. O. Mecham, D. Rowitch, C. D. Wallace, P. H. Stern, and R. M. Hoffman, "The metabolic defect of methionine dependence occurs frequently in human tumor cell lines," Biochemical and Biophysical Research Communications, vol. 117, no. 2, pp. 429434, 1983.

[6] T. Yoshioka, T. Wada, N. Uchida et al., "Anticancer efficacy in vivo and in vitro, synergy with 5-fluorouracil, and safety of recombinant methioninase," Cancer Research, vol. 58, no. 12, pp. 2583-2587, 1998.

[7] D. Sato and T. Nozaki, "Methionine gamma-lyase: the unique reaction mechanism, physiological roles, and therapeutic applications against infectious diseases and cancers," IUBMB Life, vol. 61, no. 11, pp. 1019-1028, 2009. 
[8] T. Takakura, K. Mitsushima, S. Yagi et al., "Assay method for antitumor L-methionine $\gamma$-lyase: comprehensive kinetic analysis of the complex reaction with L-methionine," Analytical Biochemistry, vol. 327, no. 2, pp. 233-240, 2004.

[9] P. Skehan, R. Storeng, D. Scudiero et al., "New colorimetric cytotoxicity assay for anticancer-drug screening," Journal of the National Cancer Institute, vol. 82, no. 13, pp. 1107-1112, 1990.

[10] V. Ali and T. Nozaki, "Current therapeutics, their problems, and sulfur-containing-amino-acid metabolism as a novel target against infections by 'amitochondriate' protozoan parasites," Clinical Microbiology Reviews, vol. 20, no. 1, pp. 164-187, 2007.

[11] B. Sharma, S. Singh, and S. S. Kanwar, "L-methionase: a therapeutic enzyme to treat malignancies," BioMed Research International, vol. 2014, Article ID 506287, 13 pages, 2014.

[12] S. Moore, D. H. Spackman, and W. H. Stein, "Chromatography of amino acids on sulphonated polystyrene resins: an improved system," Analytical Chemistry, vol. 30, no. 7, pp. 1185-1190, 1958.

[13] Difco Laboratories Incorporated, Difco Manual, Difco Laboratories Incorporated, Detroit, Mich, USA, 9th edition, 1953.

[14] K. Arfi, F. Amárita, H.-E. Spinnler, and P. Bonnarme, "Catabolism of volatile sulfur compounds precursors by Brevibacterium linens and Geotrichum candidum, two microorganisms of the cheese ecosystem," Journal of Biotechnology, vol. 105, no. 3, pp. 245-253, 2003.

[15] O. H. Lowry, N. J. Rosebrough, A. L. Farr, and R. J. Randall, "Protein measurement with the Folin phenol reagent," The Journal of Biological Chemistry, vol. 193, no. 1, pp. 265-275, 1951.

[16] W. Kreis and C. Hession, "Isolation and purification of L-methionine- $\alpha$-deamino- $\gamma$-mercaptomethane-lyase ( $\mathrm{L}$-methioninase) from Clostridium sporogenes," Cancer Research, vol. 33, no. 8, pp. 1862-1865, 1973.

[17] V. K. Lishko, O. V. Lishko, and R. M. Hoffman, "The preparation of endotoxin-free L-methionine- $\alpha$-deamino- $\gamma$ mercaptomethane-lyase (L-methioninase) from Pseudomonas putida," Protein Expression and Purification, vol. 4, no. 6, pp. 529-533, 1993.

[18] H. Tanaka, N. Esaki, T. Yamamoto, and K. Soda, "Purification and properties of methioninase from Pseudomonas ovalis," FEBS Letters, vol. 66, no. 2, pp. 307-311, 1976.

[19] R. John, "Enzyme purification and related techniques, Gel filtration," in Methods in Enzymology, W. B. Jakoby, Ed., vol. 22, pp. 287-321, Academic Press, New York, NY, USA, 1969.

[20] U. K. Laemmli, "Cleavage of structural proteins during the assembly of the head of bacteriophage T4," Nature, vol. 227, no. 5259, pp. 680-685, 1970.

[21] T. Nakayama, N. Esaki, H. Tanaka, and K. Soda, "Chemical modification of cysteine residues of L-methionine $\gamma$ lyase," Agricultural and Biological Chemistry, vol. 52, no. 1, pp. 177-183, 1988.

[22] W. A. Sundar and H. Nellaiah, "A rapid method for screening of methioninase producing Serratia marcescens species from soil," International Journal of Pharmacy and Pharmaceutical Sciences, vol. 5, no. 2, pp. 426-427, 2013.

[23] B. Dias and B. Weimer, "Purification and characterization of L-methionine $\gamma$-lyase from Brevibacterium linens BL2," Applied and Environmental Microbiology, vol. 64, no. 9, pp. 3327-3331, 1998.

[24] I. V. Manukhov, D. V. Mamaeva, S. M. Rastorguev et al., "A gene encoding L-methionine $\gamma$-lyase is present in Enterobacteriaceae family genomes: identification and characterization of Citrobacter freundii L-methionine $\gamma$-lyase," Journal of Bacteriology, vol. 187, no. 11, pp. 3889-3893, 2005.
[25] A. S. A. El-Sayed, "Purification and characterization of a new L-methioninase from solid cultures of Aspergillus flavipes," The Journal of Microbiology, vol. 49, no. 1, pp. 130-140, 2011.

[26] Y. Tan, M. Xu, H. Guo, X. Sun, T. Kubota, and R. M. Hoffman, "Anticancer efficacy of methioninase in vivo," Anticancer Research, vol. 16, no. 6, pp. 3931-3936, 1996.

[27] A. S. El-Sayed, S. A. Shouman, and H. M. Nassrat, "Pharmacokinetics, immunogenicity and anticancer efficiency of Aspergillus flavipes L-methioninase," Enzyme and Microbial Technology, vol. 51, no. 4, pp. 200-210, 2012.

[28] M. C. Martínez-Cuesta, C. Peláez, J. Eagles, M. J. Gasson, T. Requena, and S. B. Hanniffy, "YtjE from Lactococcus lactis IL1403 is a C-S lyase with $\alpha, \gamma$-elimination activity toward methionine," Applied and Environmental Microbiology, vol. 72, no. 7, pp. 4878-4884, 2006.

[29] A. S. El-Sayed, "Microbial L-methioninase: production, molecular characterization, and therapeutic applications," Applied Microbiology and Biotechnology, vol. 86, no. 2, pp. 445-467, 2010.

[30] D. Kudou, S. Misaki, M. Yamashita, T. Tamura, N. Esaki, and K. Inagaki, "The role of cysteine 116 in the active site of the antitumor enzyme L-methionine $\gamma$-lyase from Pseudomonas putida," Bioscience, Biotechnology and Biochemistry, vol. 72, no. 7, pp. 1722-1730, 2008.

[31] A. Goyer, E. Collakova, Y. Shachar-Hill, and A. D. Hanson, "Functional characterization of a methionine $\gamma$-lyase in arabidopsis and its implication in an alternative to the reverse trans-sulfuration pathway," Plant and Cell Physiology, vol. 48, no. 2, pp. 232-242, 2007.

[32] A. C. Eliot and J. F. Kirsch, "Modulation of the internal aldimine $\mathrm{p} K_{\mathrm{a}}$ 's of 1-aminocyclopropane-1-carboxylate synthase and aspartate aminotransferase by specific active site residues," Biochemistry, vol. 41, no. 11, pp. 3836-3842, 2002.

[33] H. Hori, K. Takabayashi, L. Orvis, D. A. Carson, and T. Nobori, "Gene cloning and characterization of Pseudomonas putida L-methionine- $\alpha$-deamino- $\gamma$-mercaptomethane-lyase," Cancer Research, vol. 56, no. 9, pp. 2116-2122, 1996.

[34] K. Arfi, H. Spinnler, R. Tache, and P. Bonnarme, "Production of volatile compounds by cheese-ripening yeasts: requirement for a methanethiol donor for $S$-methyl thioacetate synthesis by Kluyveromyces lactis," Applied Microbiology and Biotechnology, vol. 58, no. 4, pp. 503-510, 2002.

[35] S. B. Hanniffy, M. Philo, C. Peláez, M. J. Gasson, T. Requena, and M. C. Martínez-Cuesta, "Heterologous production of methionine- $\gamma$-lyase from Brevibacterium linens in Lactococcus lactis and formation of volatile sulfur compounds," Applied and Environmental Microbiology, vol. 75, no. 8, pp. 2326-2332, 2009.

[36] N. H. Odaa, N. Y. Yaseen, and M. T. Flaih, "Cytotoxicity of purified methionine $\gamma$-lyase produced by Pseudomonas putida on several cell lines," Iraqi Journal of Cancer and Medical Genetics, vol. 6, pp. 72-75, 2013.

[37] J. C. Colin and B. A. Law, "Isolation and characterization of L-methionine $\gamma$-demethiolase from Brevibacterium linens NCDO 739," Sciences des Aliments, vol. 9, pp. 805-812, 1989.

[38] K.-W. Thong, G. H. Coombs, and B. E. Sanderson, "LMethionine catabolism in trichomonads," Molecular and Biochemical Parasitology, vol. 23, no. 3, pp. 223-231, 1987.

[39] K. Pavani and S. V. Saradhi, "Cloning and expression of methionine- $\boldsymbol{\gamma}$-lyase (MGL) of Brevibacterium linens," International Journal of Current Microbiology and Applied Science, vol. 3, pp. 615-631, 2014. 
[40] B. C. Lockwood and G. H. Coombs, "Purification and characterization of methionine $\gamma$-lyase from Trichomonas vaginalis," Biochemical Journal, vol. 279, no. 3, pp. 675-682, 1991.

[41] H. Inoue, K. Inagaki, M. Sugimoto, N. Esaki, K. Soda, and H. Tanaka, "Structural analysis of the L-methionine $\gamma$-lyase gene from Pseudomonas putida," Journal of Biochemistry, vol. 117, no. 5, pp. 1120-1125, 1995.

[42] N. Esaki and K. Soda, "L-methionine $\gamma$-lyase from Pseudomonas putida and Aeromonas," in Methods in Enzymology, vol. 143, pp. 459-465, Elsevier, 1987.

[43] I. V. Manukhov, D. V. Mamaeva, E. A. Morozova et al., "Lmethionine $\gamma$-lyase from Citrobacter freundii: cloning of the gene and kinetic parameters of the enzyme," Biochemistry, vol. 71, no. 4, pp. 361-369, 2006.

[44] N. G. Faleev, M. V. Troitskaya, E. A. Paskonova, M. B. Saporovskaya, and V. M. Belikov, "L-methionine- $\gamma$-lyase in Citrobacter intermedius cells: stereochemical requirements with respect to the thiol structure," Enzyme and Microbial Technology, vol. 19, no. 8, pp. 590-593, 1996.

[45] M. Ferchichi, D. Hemme, and M. Nardi, "Induction of methanethiol production by Brevibacterium linens CNRZ918," Journal of General Microbiology, vol. 132, no. 11, pp. 3075-3082, 1986.

[46] A. S. El-Sayed, "L-methioninase production by Aspergillus flavipes under solid-state fermentation," Journal of Basic Microbiology, vol. 178, pp. 1187-1196, 2009.

[47] Q. Han, M. Xu, L. Tang et al., "Homogeneous, nonradioactive, enzymatic assay for plasma pyridoxal 5-phosphate," Clinical Chemistry, vol. 48, no. 9, pp. 1560-1564, 2002.

[48] J. Hu and N.-K. V. Cheung, "Methionine depletion with recombinant methioninase: in vitro and in vivo efficacy against neuroblastoma and its synergism with chemotherapeutic drugs," International Journal of Cancer, vol. 124, no. 7, pp. 1700-1706, 2009.

[49] Y. Tan, M. Xu, and R. M. Hoffman, "Broad selective efficacy of rMETase and PEG-rMETase on cancer cells in vitro," Anticancer Research, vol. 30, no. 3, pp. 793-798, 2010. 

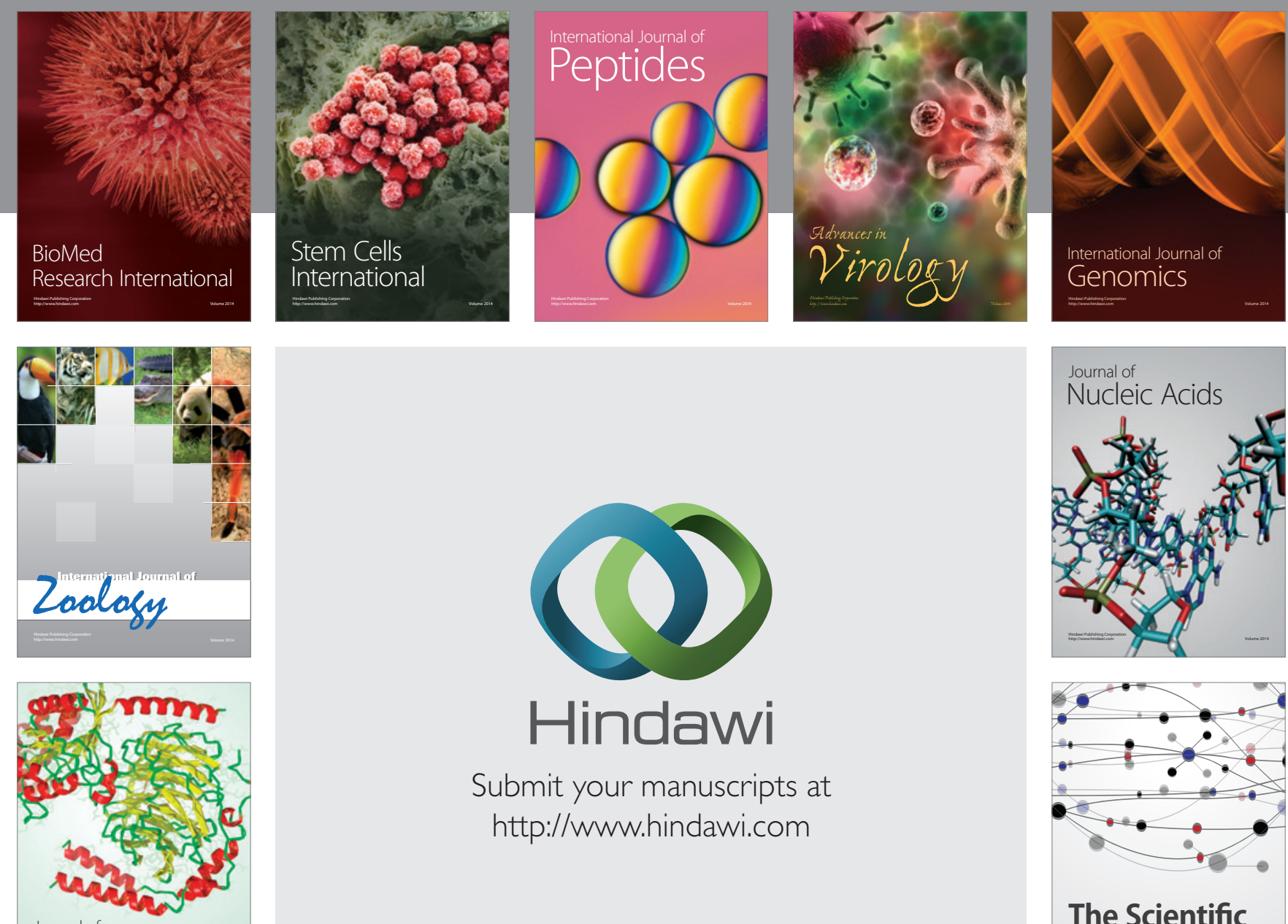

Submit your manuscripts at

http://www.hindawi.com

Journal of
Signal Transduction
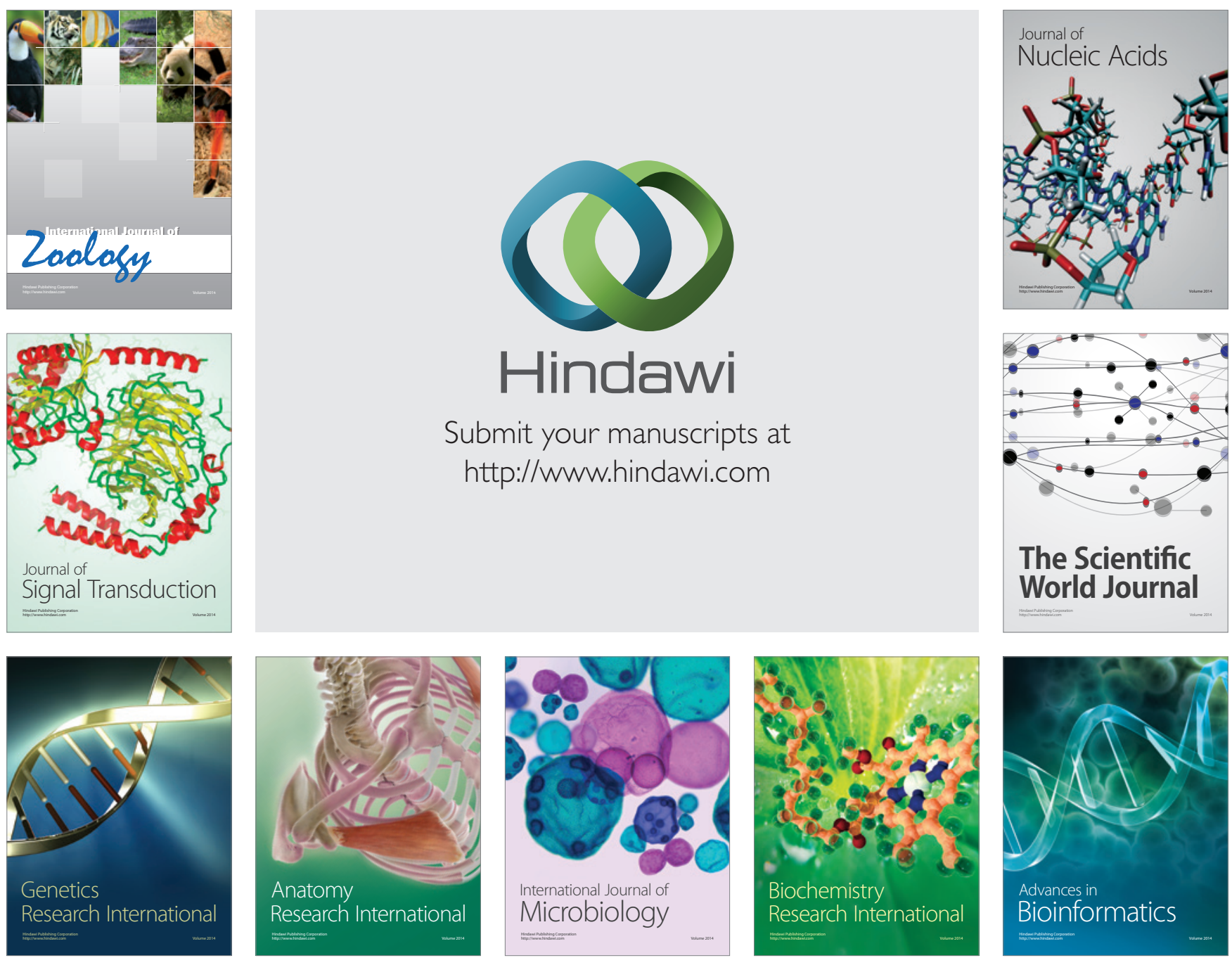

The Scientific World Journal
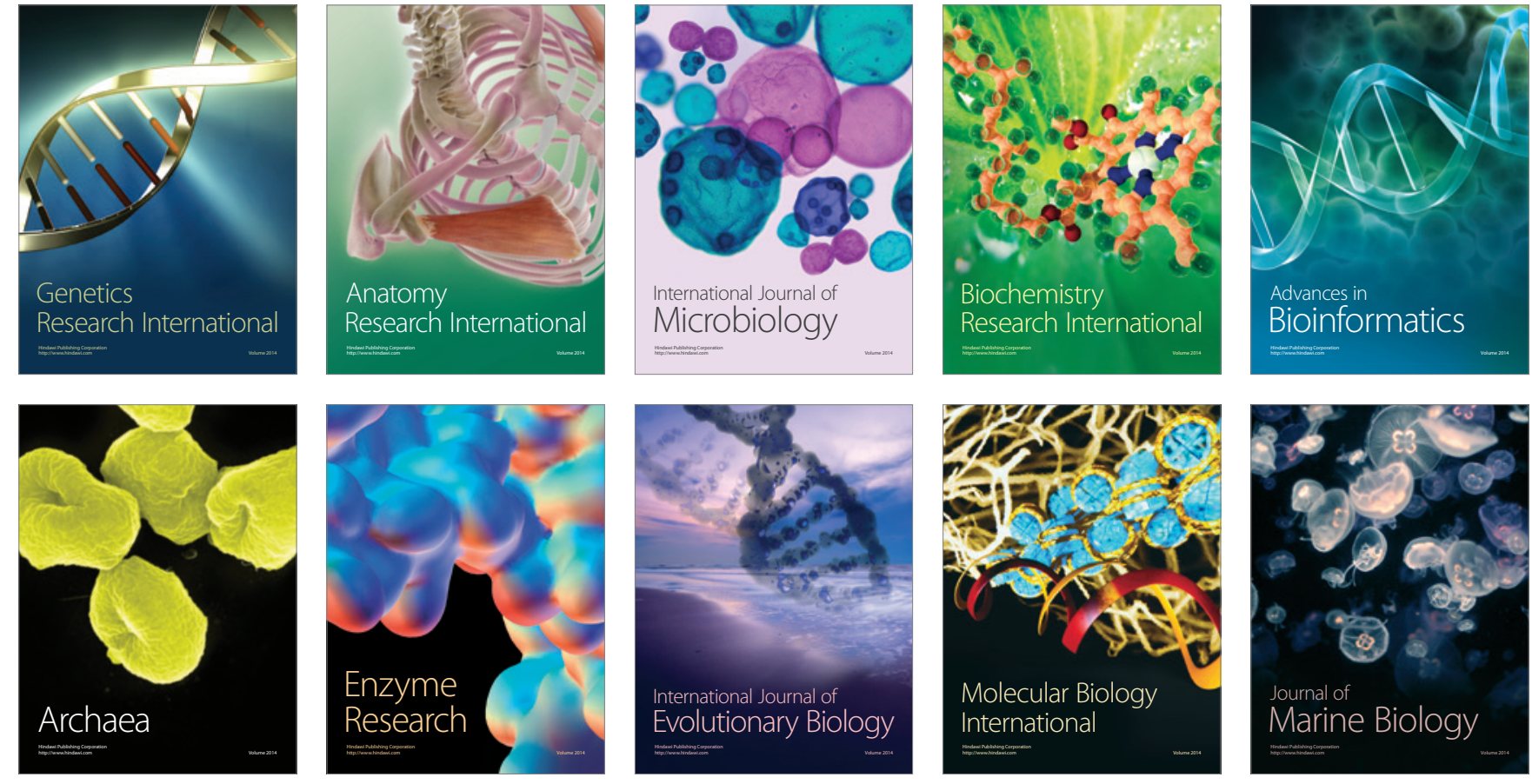